\title{
IMPLEMENTING A NETWORK OF WEATHER AND AGROMETEOROLOGICAL STATIONS: A CASE STUDY IN TIMOR-LESTE
}

José A. ANDRADE ${ }^{1}$

Tiago G. Silva ${ }^{2}$

Hugo M. Trindade ${ }^{2}$

Claudino Nabais ${ }^{2}$

\begin{abstract}
Modern and developed agriculture requires permanent and reliable monitoring of both meteorological/climatic and biological variables in agrometeorological stations. The main objective of the work was to implement a network of agrometeorological stations in Timor-Leste, a developing Southeast Asian country with irregular weather/climate monitoring for the past decades mainly due to political instability (wars, occupations,...) and at that time still devoid of any national network of meteorological stations. For this purpose, we took into account the administrative division of the country and the available agro-climatic zoning, the location of the existing stations and of those with relevant historical records, the agricultural and forestry practices in the country, the existing agricultural research centres as well as the structure and composition of the existing stations (number and type of sensors, communication system,...) and the human resources to ensure a proper stations network management. The implementation of a network composed of 50 weather stations was proposed to cover the entire national territory $\left(299.34 \mathrm{~km}^{2} /\right.$ station). A network of agrometeorological stations was purposed by strengthening the equipment in 15 out of these 50 weather stations with sensors that measure agrometeorological parameters and by assuring the ability to maintain it. Flexibility in the composition of each network has been safeguarded for the purpose of responding to any substantial change in financial or technical conditions in an ever-changing country. All methodologies and recommendations were discussed on the basis of a "management concept for weather stations" which requires not
\end{abstract}

Recebido: janeiro 2018. Aceite: maio 2018.

1 Researcher at Instituto de Ciências Agrárias e Ambientais (ICAAM), Professor at Departamento de Geociências, Universidade de Évora, Colégio Luís António Verney, R. Romão Ramalho, 59, 7000-671, Évora, Portugal. E-mail: zalex@uevora.pt

2 Technician at MAP of Timor-Leste, Camões - Institute for Cooperation and Language, Global Climate Change Alliance Programme to Timor-Leste, Dili, Timor-Leste. E-mail: taigogmb@gmail.com; hugomigueltrindade@gmail.com; claudino nabais@ yahoo.com 
only scientific rigor in the choice of locations to be monitored, but also maintenance, human resources training and the involvement of beneficiary populations.

Keywords: Agrometeorological stations; weather stations; network of agrometeorological stations; Timor-Leste; agro-climatic zoning.

RESUMO - IMPLEMENTAÇÃO DE UMA REDE DE ESTAÇÕES AGROMETEOROLÓGICAS EM TIMOR-LESTE: UM ESTUDO DE CASO. Uma agricultura moderna e desenvolvida requer monitorização permanente e fidedigna de variáveis meteorológicas/ climáticas e biológicas em estações agrometeorológicas. O objetivo deste trabalho consistiu em propor a implementação uma rede de estações agrometeorológicas em Timor-Leste, um país em desenvolvimento do Sudeste Asiático, com monitorização climática/meteorológica irregular nas últimas décadas, principalmente devido à instabilidade política (guerras, ocupações,...) e que, à data, era desprovido de qualquer rede nacional de estações meteorológicas. Para tal, foram tidos em conta fatores como a divisão administrativa do país e a zonagem agroclimática disponível, a localização das estações existentes e daquelas com registos históricos relevantes, as práticas agrícolas e florestais no país, os centros de investigação agrícola existentes, bem como a estrutura e composição das estações existentes (número e tipo de sensores, sistema de comunicação,...) e os recursos humanos que garantam uma adequada gestão das redes de estações. Foi proposta a implementação de uma rede composta por 50 estações meteorológicas para cobrir todo o território nacional (299,34 km²/ estação) e, com a adição de medidores de parâmetros agrometeorológicos em 15 destas estações, criada uma rede nacional de estações agrometeorológicas. Com o objetivo de responder a qualquer alteração substancial nas condições financeiras ou técnicas num país em constante mudança, foi salvaguardada a flexibilidade na composição de cada rede. Todas as metodologias e recomendações foram discutidas com base num "conceito de gestão para estações meteorológicas", que exige não apenas rigor científico na escolha de locais a serem monitorizados, mas também manutenção, formação de recursos humanos e envolvimento de populações beneficiárias.

Palavras-chave: Estações agrometeorológicas; estações meteorológicas; rede de estações agrometeorológicas; Timor-Leste; zonagem agroclimática.

RÉSUMÉ - MISE EN PLACE D’UN RESEAU DE STATIONS AGRO-METEOROLOGIQUES EN TIMOR-LESTE. Un suivi permanent et fiable des variables météorologiques, climatiques et biologiques, par un réseau de stations agrométéorologiques, est indispensable à la pratique d'une agriculture moderne bien développée. On propose ici la mise en place d'un tel réseau dans ce pays en voie de développement de l'Asie du Sud Est. En effet, l'instabilité politique qu'il a connue au cours des dernières décennies avait empêché le développement d'un réseau national de stations météorologiques. On a considéré, à cet effet, la division administrative du pays et ce quon sait actuellement de ses zones agro-climatiques, la position et les caractéristiques des stations existantes et les ressources humaines indispensables pour en assurer une gestion correcte, On propose la mise en place d'un réseau de 50 stations météorologiques avec, en moyenne, $300 \mathrm{~km}^{2}$ par station; dans 15 de ces stations, des paramètres agrométéorologiques seraient aussi mesurés. On a maintenu une certaine flexibilité de ces réseaux, afin de pouvoir faire face à toute modification substantielle des conditions financières ou techniques d'un pays en constante 
évolution. Toutes ces propositions sont basées sur un «concept de gestion des stations météorologiques», qui exige non seulement la rigueur scientifique dans le choix des sites d'observation, mais encore la formation et le maintien des ressources humaines, et l'implication des populations bénéficiaires.

Mots clés: Stations agrométéorologiques; stations météorologiques; réseau de stations agrométéorologiques; Timor-Leste; zonage agroclimatique.

\section{INTRODUCTION}

Both the planning and operation of many human activities (e.g., agriculture, industry, transportation, tourism, fisheries, aeronautic, research) rely on information generated by weather (or climate) data, in turn registered in different types of weather stations. A judicious dispersion of weather stations over a given area for a specific purpose (e.g., climatological, agrometeorological...) and their joint administration (thus constituting networks) are thus essential practices to support societal and economic development of any territory (World Meteorological Organization (WMO), 2007). The long-term meteorological series recorded from the networks of weather stations are even cultural goods decisive in both the characterization and identification of nations and territories (Katušin, 1994). The optimization of a network of weather stations should take into account not only the physiographic factors that determine, in large measure, the existing climatic diversity in the area it covers, but also the location of economic activities that require the weather (or climate) data and the financial and human resources available in each case. Specifically, a developed and sustainable agriculture requires a permanent and reliable monitoring of both meteorological/climatic and biological variables in agrometeorological stations, which should be preferably located in regions of agricultural and forestry activities (WMO, 2010). Despite the obvious need for this type of station, most countries in Asia and Oceania only started agrometeorological operations after the Second World War (Kamali, Nguye, Van Viet, \& Rahimi, 2006).

Developing countries, mainly those with a history of frequent conflicts, present a deficient number of operational weather stations, often poorly composed and improperly distributed within their territories, and without regular operation to ensure the continuity of records for a sufficiently long period of time. Troubles are often reinforced by financial drawbacks, poor communication and insufficient human resources to ensure an adequate maintenance of the stations. It is then imperative to develop a broad "concept of weather stations management" that includes not only the implementation and functioning of the stations but also their adequate maintenance among other parameters (Andrade, 2015), in order to ensure consistent practices in performing observations, in handling climate records and in maintaining the necessary quality and utility of the services provided (WMO, 2011). 
Timor-Leste is an independent young (since 2002) Southeast Asian country, having been a Portuguese colony for centuries, although occupied by the Japanese during the 2nd World War and by the Indonesians between 1975 and 1999. Such events marked indelibly the operability of the weather stations installed from 1914 (the year in which the first stations began to operate). From 1941 to 1952 and from 1975 to about 2002 no meteorological data are available, mainly due to the paralysis of the operation of the stations (destruction and/or inactivation). Rescuing long-term data for scientific studies of various kinds (including descriptions of climate) is then a very difficult task. At the time of independence only two stations operated on a regular basis (at the international airports of Dili and Baucau). Thereafter, weather conditions of more than forty locations had been monitored by four operators in an independent way. Not surprisingly, some locations were monitored in duplicate while several areas of the territory with specific agro-ecological characteristics were not monitored. In addition, 14 locations with relevant historical records (from the time of the Portuguese administration) were not again monitored. Despite remarkable progress in the last decade, other constraints prevented the proper functioning of a good part of the stations observed (poor location of some of them, breach of the implementation of basic rules, various breakdowns...). Finally, no station provided at present biological information (i.e., according to the terminology suggested by World Meteorological Organization (WMO), there is no agrometeorological stations in Timor-Leste). Identical reality was still found around 2004 in some countries of Asia and Oceania (Kamali et al., 2006).

The main objective of this work was to implement, in a first stage, a national network of meteorological stations and, in a second stage, a network of agrometeorological stations established therefrom. Both networks should cover the entire national territory and represent simultaneously its climate and its agro-ecological diversity, taking into account the maintenance capabilities of each station in order to ensure their long-term sustainability. Furthermore, a methodology adapted to the specific situation described above is presented and discussed.

\section{GEOGRAPHICAL BACKGROUND}

\section{Territory and population}

Timor-Leste occupies the east side of Timor island, the nearby islands of Atauro (at the northern, belonging to the municipality of Dili, the capital) and Jaco (at the eastern tip of the island) and the enclave of Oecusse (Special Administrative Region of Oecusse-Ambeno on the northwest side of the island, within Indonesian Timor) (fig. 1). It lies over an area of $14967 \mathrm{~km}^{2}$, between latitude $8^{\circ} 08^{\prime} \mathrm{S}$ and $9^{\circ} 32^{\prime} \mathrm{S}$ and longitude $124^{\circ} 02^{\prime} \mathrm{E}$ and $127^{\circ} 32^{\prime} \mathrm{E}$. Timor-Leste is surrounded to the north by the Indonesian islands, while the Timor Sea separates to the south the island from Australia. Timor-Leste is divided into twelve municipalities (mun.) and one special administrative region (sar). The soil in Timor-Leste is mainly occupied by cropped land, agro-forestry areas or typical forest, savanna, heaths and sand, 
while the urban space represents less than $1 \%$ of the total area of the territory (mainly confined to Dili, the capital of Timor-Leste) (Universidade Técnica de Lisboa (UTL) \& Faculdade de Arquitectura de Lisboa (FA), 2002). The land communication routes are still quite poor and are therefore an additional handicap for the management of any network of weather stations. According to the available data from 2015 (United Nations Educational, Scientific and Cultural Organization (UNESCO), 2015), agricultural and forestry areas represented $25.6 \%$ and $46.1 \%$ of the country area, respectively. About two thirds of the population lives in rural areas (a similar proportion of the economically active population works in agriculture, which represents $18.4 \%$ of the total Timorese GDP).

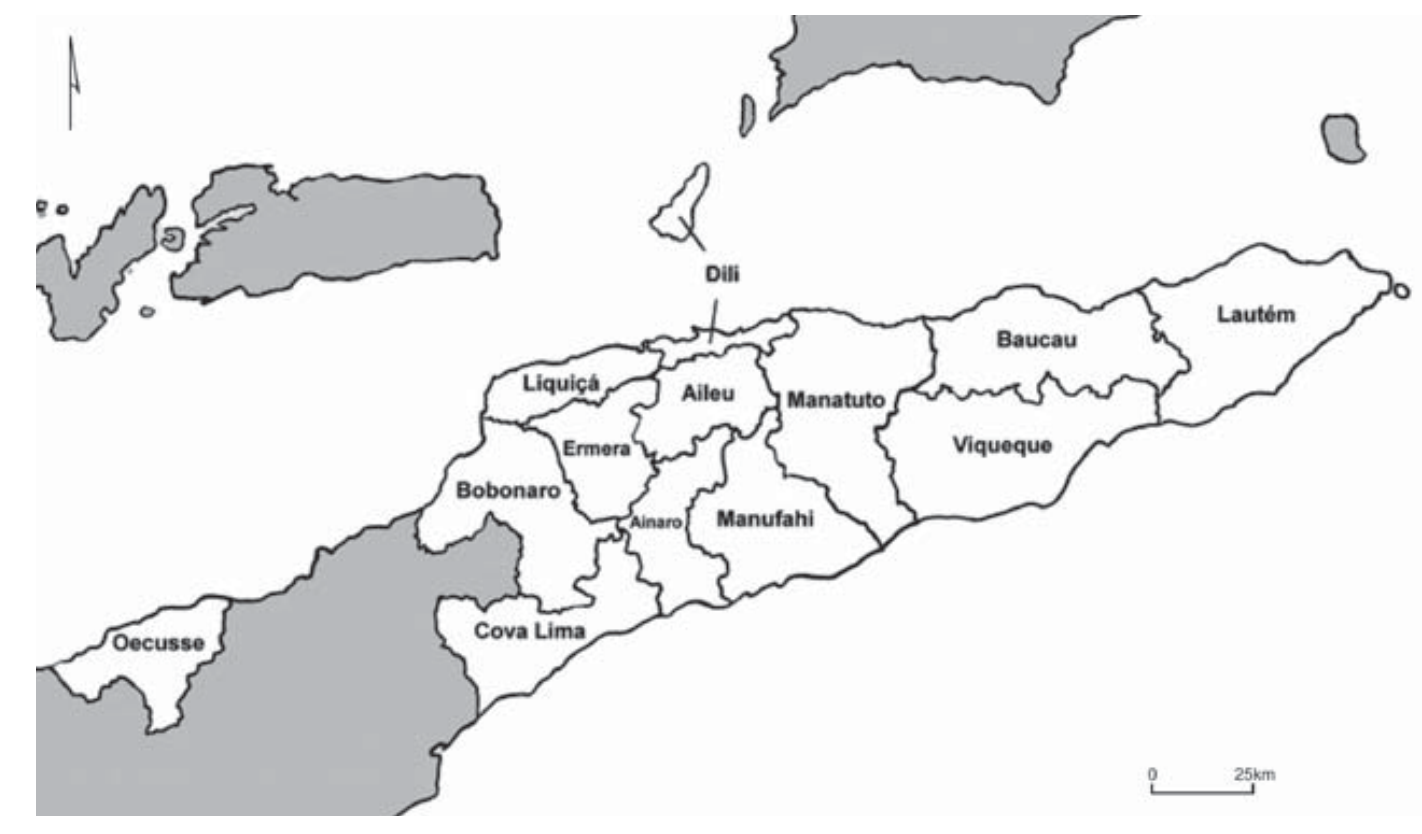

Fig. 1 -Territory of Timor-Leste, localization and administrative division.

Fig. 1 - Território de Timor-Leste, localização e divisão administrativa. Source: Timor Agora (2015)

The Timorese population is very young (42.4\% of the population in 2015 are aged 14 years or younger) and increasingly educated (UNESCO, 2015). According to this institution, the 'gross enrolment ratio' (the ratio of the number of students enrolled in a given level of education to those the official school-age population for that particular grade level) referred to the secondary and tertiary education levels were, in 2010, about $67 \%$ and $18 \%$, respectively, These values encourage the short-term suppression of the lack of sufficient qualified technicians to ensure tasks under the operation of a meteorological network as supervision, maintenance, inspection, data processing, forecasting and warning services, etc.

\section{Relief and climate}

Most of the country is mountainous (fig. 2). A central SW-NE oriented crest separate the country into two distinct parts, one facing north with steep slopes and an irregular 
orography, while that facing south has smoother slopes and more varied relief. The average altitude decreases from west to east. Most of the highest points $(2000 \mathrm{~m}$ above sea level) are located in the municipalities of Ermera, Ainaro and Bobonaro (Monte Ramelau, Cablaque, Merique and Loelaco) while in the east side of the country only two isolated mountains along the border between the municipalities of Viqueque and Baucau (Monte Perdido and Matebian) exhibit significant elevations. Two plateaus are noteworthy for their length: that of Baucau, between the northern coast and Monte Perdido and that of Lospalos in the east end of the island. Elevation/orography and proximity of the sea, together with the general circulation of the atmosphere (the seasonal migrations of the Intertropical Convergence Zone) and the associated monsoon regime, are the main factors that determine the climate in Timor-Leste.

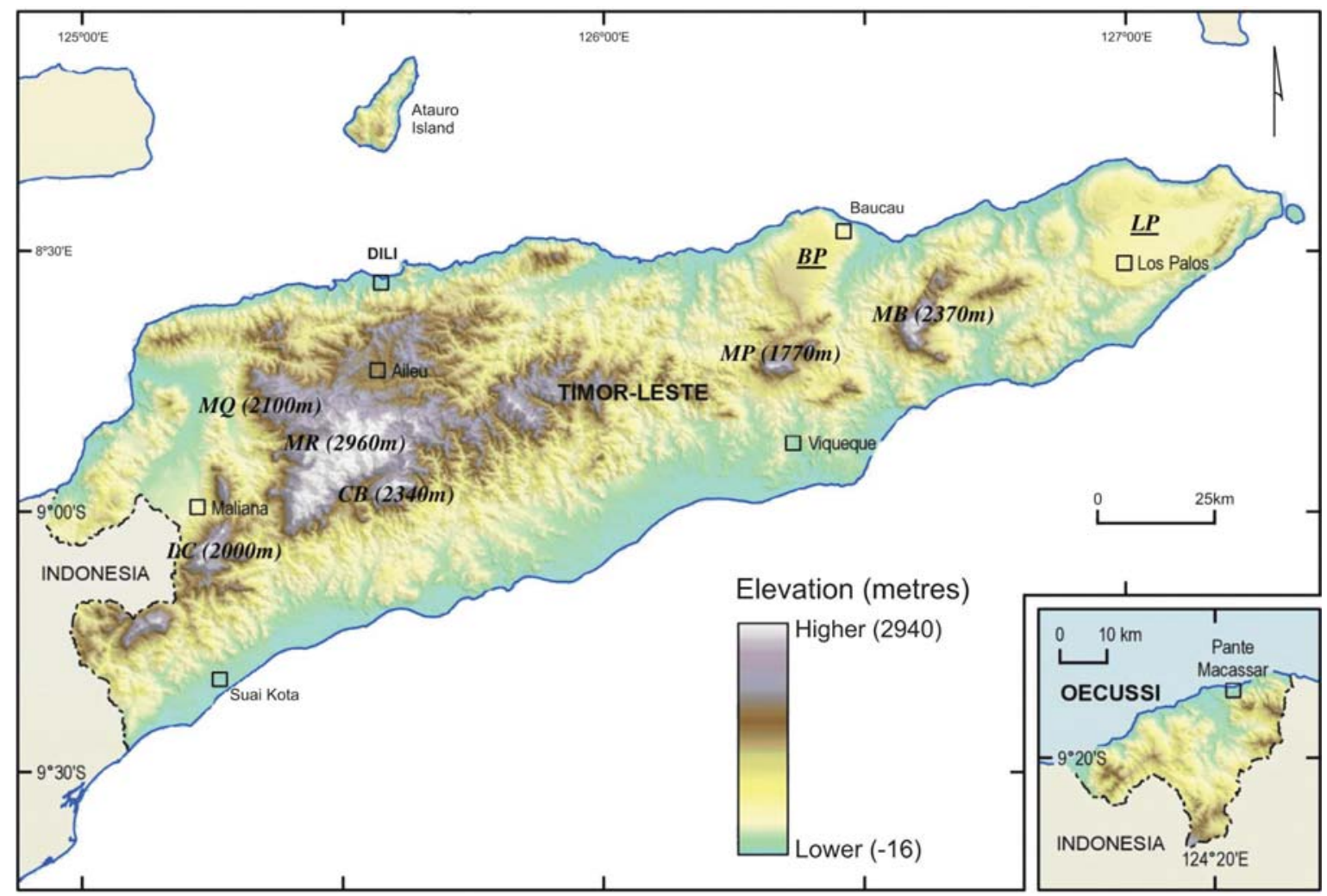

Fig. 2 - Relief of Timor-Leste, including the main elevations and the two most important plateaus: $M R$ (Monte Ramelau), MB (Matebian), CB (Cablaque), LC (Loelaco), MQ (Merique), MP (Mundo

Perdido), $\underline{B P}$ (Baucau Plateau) and $\underline{L P}$ (Lospalos Plateau). Colour figure available online.

Fig. 2 - Relevo de Timor Leste, incluindo as principais elevações e os dois mais importantes planaltos: MR (Monte Ramelau), MB (Matebian), CB (Cablaque), LC (Loelaco), MQ (Merique) MP (Mundo

Perdido), $\underline{B P}$ (Baucau Plateau) and $\underline{L P}$ (Lospalos Plateau). Figura a cores disponível online.

Source: Seeds of Life (2013)

Despite the lack of sufficiently long time series of temperature and precipitation in large areas of the Timor-Leste territory, the thermal uniformity, which characterizes the climate in tropical areas, allows us to use the existing database as a guide to a climate pattern. According to Köppen climate classification (Sousa, 1972; Peel, Finlayson, \& McMahon, 2007) the climate types A (tropical rainy), B (dry) and C (temperate rainy) are 
represented in the territory. The climate type A is largely prevalent, while climate type B is only represented in the northeast of the country (northern areas in the municipality of Manatuto and some areas along the north coast of Baucau) and climate type $\mathrm{C}$ dominates in the hilliest areas only (altitudes above $1100-1200 \mathrm{~m}$ ). The rainy season coincides with the hottest season (from October to March) in most of the territory (climate sub-type $w$, which normally accompanies climate type $\mathrm{A}$ and, sometimes, type $\mathrm{C}$ at the highest points of the territory), but it is extended until June-July in some southern and eastern slopes of island, due to the southeast monsoon, which explains the existence of one more peak rainfall throughout the year (the sub-type $w^{\prime}$ is used for this case). In certain places, the precipitation in the dry season it is still sufficiently high to use the symbol $m$ as a climate sub-type.

\section{Agro-climatic zoning}

Agro-climatic zoning identifies areas with different potential yields for crops by using bioclimatic limits (van Wart et al., 2013). Based mainly on factors such as elevation (El) and rainfall $(\mathrm{R})$ and taking into account the central crest that transverses the territory from west to east, (Advanced Research Projects Agency Network (ARPAPET), 1996), divided Timor-Leste into six different "agro-climatic" zones (acz) (fig. 3). The zones are approximately parallel, closely reflecting the importance of the relief factor (elevation or topography). Areas facing to the north $\left(\mathrm{N}_{\mathrm{lw}}, \mathrm{N}_{\mathrm{sl}}\right.$ and $\left.\mathrm{N}_{\mathrm{up}}\right)$ account for $53 \%(10 \%, 23 \%$ and $20 \%$, respectively) of the total area, while those facing to the south $\left(\mathrm{S}_{\mathrm{up}}, \mathrm{S}_{\mathrm{sl}}, \mathrm{S}_{\mathrm{lw}}\right)$ represent $47 \%$ (15\%, $21 \%$ and $11 \%$, respectively).

By overlapping the map of figure 1 (thirteen municipalities) with that of figure 3 (six agro-climatic zones), fifty-four (54) combinations (mun. $x$ acz) were obtained. 
represented in the territory. The climate type A is largely prevalent, while climate type B is only represented in the northeast of the country (northern areas in the municipality of Manatuto and some areas along the north coast of Baucau) and climate type $\mathrm{C}$ dominates in the hilliest areas only (altitudes above $1100-1200 \mathrm{~m}$ ). The rainy season coincides with the hottest season (from October to March) in most of the territory (climate sub-type $w$, which normally accompanies climate type $\mathrm{A}$ and, sometimes, type $\mathrm{C}$ at the highest points of the territory), but it is extended until June-July in some southern and eastern slopes of island, due to the southeast monsoon, which explains the existence of one more peak rainfall throughout the year (the sub-type $w^{\prime}$ is used for this case). In certain places, the precipitation in the dry season it is still sufficiently high to use the symbol $m$ as a climate sub-type.

\section{Agro-climatic zoning}

Agro-climatic zoning identifies areas with different potential yields for crops by using bioclimatic limits (van Wart et al., 2013). Based mainly on factors such as elevation (El) and rainfall $(\mathrm{R})$ and taking into account the central crest that transverses the territory from west to east, (Advanced Research Projects Agency Network (ARPAPET), 1996), divided Timor-Leste into six different "agro-climatic" zones (acz) (fig. 3). The zones are approximately parallel, closely reflecting the importance of the relief factor (elevation or topography). Areas facing to the north $\left(\mathrm{N}_{\mathrm{lw}}, \mathrm{N}_{\mathrm{sl}}\right.$ and $\left.\mathrm{N}_{\mathrm{up}}\right)$ account for $53 \%(10 \%, 23 \%$ and $20 \%$, respectively) of the total area, while those facing to the south $\left(\mathrm{S}_{\mathrm{up}}, \mathrm{S}_{\mathrm{sl}}, \mathrm{S}_{\mathrm{lw}}\right)$ represent $47 \%$ (15\%, $21 \%$ and $11 \%$, respectively).

By overlapping the map of figure 1 (thirteen municipalities) with that of figure 3 (six agro-climatic zones), fifty-four (54) combinations (mun. $x$ acz) were obtained.

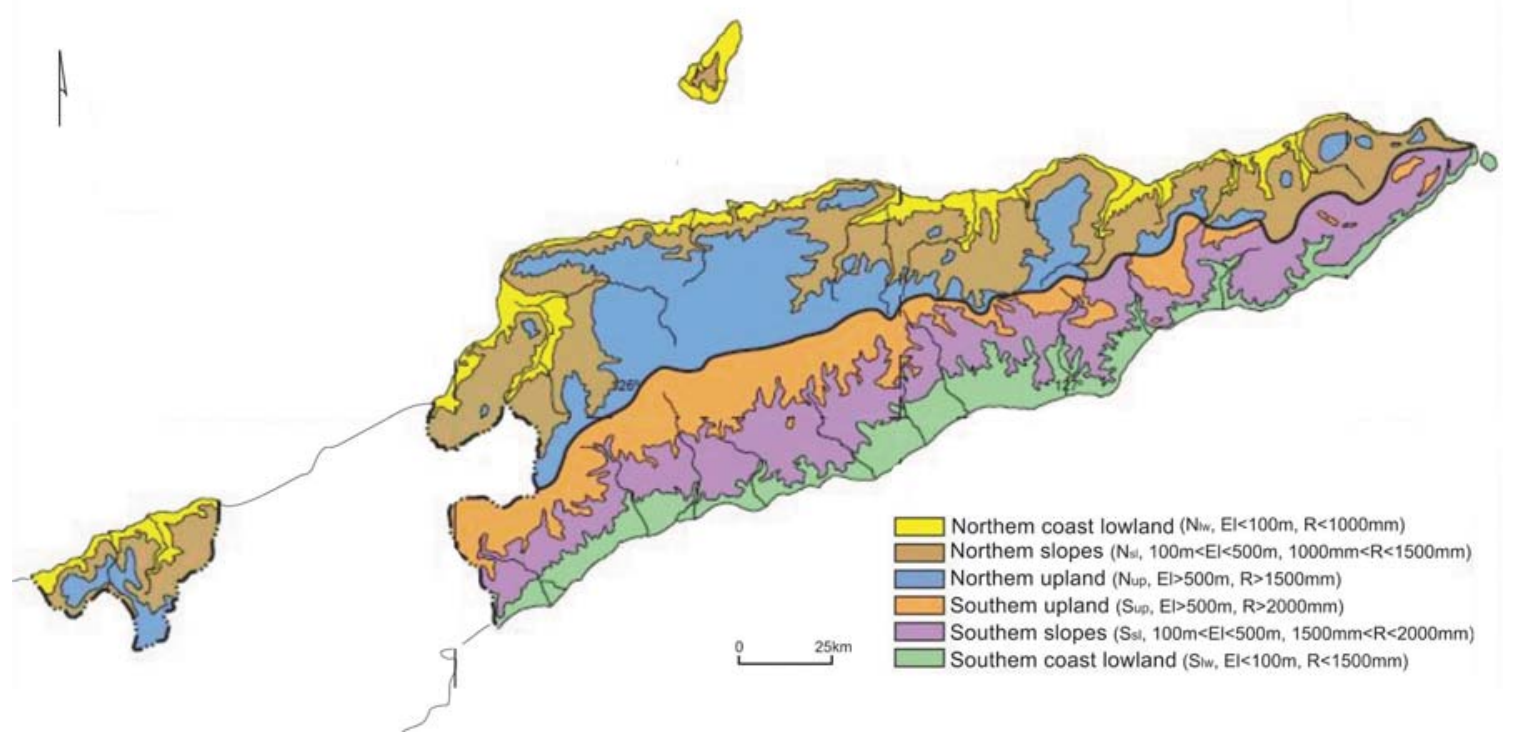

Fig. 3 - The Agro-Climatic Zones of Timor-Leste. Colour figure available online.

Fig. 3 - As Zonas Agroclimáticas de Timor-Leste. Figura a cores disponível online. Source: Advanced Research Projects Agency Network (ARPAPET) (1996) 
Table I - Existing stations (location, municipality, type of weather station, operator). AWS- Automatic Weather Station; MWS - Manual Weather Station.

Quadro I - Estações existentes (localização, município, tipo de estação, operador). AWS- Estação meteorológica automática; MWS - Estação meteorológica manual.

\begin{tabular}{|c|c|c|c|}
\hline Mun./sar & Location & WS - Model & Operator \\
\hline \multirow{4}{*}{$\begin{array}{l}\text { Aileu } \\
\text { (Al) }\end{array}$} & Aileu $^{\star}$ & AWS-Enerco 405 & ALGIS \\
\hline & Quinta Portugal & AWS-Hobo Standard & SoL \\
\hline & Aucumau & AWS-Hobo Micro & SoL \\
\hline & Seloi Malere & AWS-Hobo Micro & SoL \\
\hline \multirow{5}{*}{$\begin{array}{l}\text { Ainaro } \\
(\mathrm{An})\end{array}$} & Urulefa† & AWS-Hobo Standard & SoL \\
\hline & Aituto $\dagger$ & AWS-Hobo Micro & SoL \\
\hline & 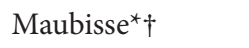 & AWS-Enerco 405 & ALGIS \\
\hline & Ainaro $^{*}$ & AWS-Enerco 420 & ALGIS \\
\hline & Hato Builico ${ }^{*} \dagger$ & AWS-Hobo Micro (GSM) & SoL \\
\hline \multirow{8}{*}{$\begin{array}{l}\text { Baucau } \\
\text { (Bc) }\end{array}$} & Fatumaca & AWS-Enerco 420 & ALGIS \\
\hline & Vemase & AWS-Hobo Micro (GSM) & JICA \\
\hline & Darasula & AWS-Hobo Standard & SoL \\
\hline & Venilale & AWS-Hobo Micro & SoL \\
\hline & Baguia* & AWS-Hobo Micro (GSM) & SoL \\
\hline & Triloro $^{*}$ & MWS & DNMG \\
\hline & Fatulia & AWS-Hobo Micro & SoL \\
\hline & Seical & AWS-Hobo Micro (GSM) & JICA \\
\hline \multirow{4}{*}{ Bobonaro (Bb) } & Balibó & MWS & ALGIS \\
\hline & Ritabau & AWS-Hobo Micro & SoL \\
\hline & Balibó & AWS-Hobo Micro & SoL \\
\hline & Maliana $^{*}$ & AWS-Enerco 420 & ALGIS \\
\hline \multirow{3}{*}{ Covalima (Cv) } & Suai $^{\star}$ & AWS-Enerco 420 & ALGIS \\
\hline & Fohoren & MWS & ALGIS \\
\hline & Fohoren & AWS-Hobo Micro (GSM) & SoL \\
\hline \multirow{4}{*}{$\begin{array}{l}\text { Dili } \\
\text { (Dl) }\end{array}$} & Comoro $^{\star}$ & MWS & DNMG \\
\hline & Atauro/Maumeta* & AWS-Hobo Micro (Sat) & SoL \\
\hline & Dare $^{*}$ & AWS-Enerco 405 & ALGIS \\
\hline & Hera & MWS & ALGIS \\
\hline \multirow{3}{*}{$\begin{array}{l}\text { Ermera } \\
(\mathrm{Em})\end{array}$} & Ermera $^{\star} \dagger$ & AWS- Enerco 420 & ALGIS \\
\hline & Gleno $^{*}$ & MWS & ALGIS \\
\hline & Atsabe $\dagger$ & MWS & ALGIS \\
\hline \multirow{3}{*}{$\begin{array}{l}\text { Lautem } \\
(\mathrm{Lt})\end{array}$} & Fuiloro & AWS-Hobo Micro & SoL \\
\hline & Luro & AWS-Hobo Micro & SoL \\
\hline & Fuiloro & AWS-Enerco 420 & ALGIS \\
\hline \multirow{3}{*}{$\begin{array}{l}\text { Liquiçá } \\
\text { (Lq) }\end{array}$} & Liquiçáa $^{*}$ & MWS & ALGIS \\
\hline & Fazenda Algarve* & AWS-Hobo Micro & SoL \\
\hline & Loes & AWS-Hobo Standard & SoL \\
\hline \multirow{4}{*}{ Manatuto (Mt) } & Manatuto $^{\star}$ & AWS- Enerco 420 & ALGIS \\
\hline & Laklubar $^{*} \dagger$ & AWS-Hobo Micro (GSM) & SoL \\
\hline & Natarbora & MWS & ALGIS \\
\hline & Cribas & AWS-Hobo Micro (GSM) & JICA \\
\hline \multirow{6}{*}{ Manufahi (Mf) } & Same $^{\star}$ & AWS-Hobo Micro & SoL \\
\hline & Dotik & AWS-Hobo Micro & SoL \\
\hline & Betano & AWS- Enerco 405 & ALGIS \\
\hline & Betano & AWS-Hobo Standard & SoL \\
\hline & Caraulum & AWS-Hobo Micro (GSM) & JICA \\
\hline & Sahen & AWS-Hobo Micro (GSM) & JICA \\
\hline Oecusse (Oc) & Pante Macassar ${ }^{\star}$ & AWS-Hobo Micro (Sat) & SoL \\
\hline \multirow{3}{*}{ Viqueque (Vq) } & Ossu $^{*}$ & AWS-Hobo Micro & SoL \\
\hline & Irabere & AWS-Hobo Micro (GSM) & JICA \\
\hline & Bahalara-uain & AWS-Hobo Micro & SoL \\
\hline
\end{tabular}

* Stations with relevant historical records (more than 10 consecutive years); †Stations located above $1000 \mathrm{~m}$ of elevation. 


\subsection{National network of weather stations}

Four factors were considered in the distribution of stations over the territory of Timor-Leste. The administrative factor suggested the presence of weather stations in all municipalities, thereby contributing to both national and social cohesion. The agro-climatic factor crossed physical factors such as altitude, topography and climate parameters thus ensuring that the climate diversity was properly represented in the network. The socio-economic factor took into account the demographics of the country, the human resources to ensure the proper functioning of a network of stations, the network of agriculture technical schools and research centres, the persistence or prediction of the existence of strategic economic activities, namely those of agricultural and/or forestry nature. Finally, the empirical factor highlighted the existing weather stations and the corresponding operation time, their actual location and their components (sensors, communications...) and the operation time (Czaczyk, 2012), and also the locations with relevant historical records, enhancing the corresponding climate characterization and its diversity, and making the management of natural resources easier.

The choice of locations in the territory of Timor-Leste to be included in the national network of weather stations followed three distinct criteria:

a) Representativeness: all the administrative divisions (municipalities and Oecusse), and in each of them, the most representative agro-climatic zones (area percentage, economical relevance...) should be represented; the network density should be strengthened in mountainous areas due to increased variability of important climate/meteorological parameters such as rainfall or wind and in agro-climatic zones where some topoclimatic diversity is detectable or expected;

b) Historical relevance: locations without weather stations at the present time but with a significant historical of records over the past century (under Portuguese administration), should be involved again in the new network, preferably with complete stations;

c) Sustainability: each location should be accessible (communications) and proper management ensured, which demands, among other requirements, local human and financial resources for an adequate maintenance. These criteria (and also the former) should be directly linked to a management concept for weather stations (Andrade, 2015).

The above criteria are compatible with WMO standards (WMO, 2014). Taking into account the scarcity of resources, the establishment of a weather station network covering the entire territory of Timor-Leste requires the optimization of them, which involves the relocation of some of the existing stations and, exceptionally, the purchase of new equipment.

\subsection{National network of agrometeorological stations}

Added to the factors that will determine the distribution of weather stations in a given territory (WMO, 2007), spatial variations of natural vegetation, main crops and 
agricultural methods should also be taken into account when a network of agrometeorological stations is established (WMO, 2010).

A network of agrometeorological stations in Timor-Leste was formed by joining the WSs (at least) included in the national network that in each municipality best fulfil the objectives outlined for the operation of this type of station (location in large agricultural or forestry areas, highly specialized maintenance, accessibility...). Hence, locations inside agricultural areas occupied by the most representative and strategic crops (maize, rice, cassava and coffee) or forestry activities (sandalwood and teak stands) should be preferred. In each area, the precise location should also depend on the type of soil, being favoured the major units (Cambisols, Luvisols and Vertisols). Since all they require a professional staff responsible by their installation, maintenance and transmission of data by the communication systems available (GSM, SAT...), the choice of experimental farms, agricultural schools (or colleges) and locations close (or even inside) to the services or facilities of municipal delegations of the Timorese Ministry of Agriculture and Fisheries of Timor-Leste would always be the most suitable. The most complete equipment available should be used in this network thus changes of currently installed models between locations could be a valid option. This methodology also allows this network to meet the criteria of representativeness and sustainability mentioned above.

\section{RESULTS AND DISCUSSION}

\section{Network of weather stations}

16 out of 54 combinations (mun. $x a c z$ ) were not considered because they represent insignificant areas in each municipality (less than $20 \%$ of the total area). For different reasons, no stations have been designated to operate in 3 out of the remaining 38 areas: Oc $x \mathrm{~N}_{\mathrm{up}}$ for logistical reasons while Lq $\mathrm{x} \mathrm{N}_{\mathrm{sl}}$ and $\mathrm{Bb} \mathrm{x} \mathrm{N}_{\mathrm{lw}}$ were represented by AWS installed in neighbouring areas ( $\mathrm{Em} \mathrm{x} \mathrm{N}_{\mathrm{sl}}$ and Lq $\times \mathrm{N}_{\mathrm{lw}}$, respectively). Figure 4 shows the way in which those combinations (35) were filled by weather stations and the criteria associated with each step. Table II shows all the 50 locations for which it was proposed to install and operate meteorological stations (corresponding to a density of $299.34 \mathrm{~km}^{2} /$ station). In a first step, each of the 35 combinations considered was equipped with a weather station (all of them are mentioned in the table II with the symbol ${ }^{*}$ ). For this purpose, 27 locations were represented by the existing stations while 8 of them should be equipped with new stations. In a second step, 9 combinations were strengthened with 15 WS (all marked with the symbol $\dagger$ in the table II) in order to (a) give continuity to records with historical relevance stations and/or (b) improving the representation of the climate diversity in the country (influence of elevation on temperature and precipitation regime in the southeast zone). 11 stations were added (including 4 new WS) to monitor locations with historical relevance ( 3 of these also reinforce the representation of climate diversity, including one located in the mountainous zone) while 2 WS only enhanced the represen- 
tativeness of the mountainous region on the network. In spite of being managed independently of the other weather stations (by the DNMG and not by the MAP), those located in Comoro and Triloro will also be part of the national network, strengthening the repre-

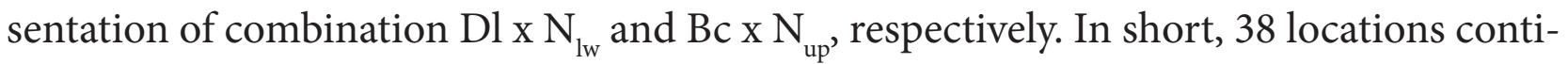
nue to be monitored with existing stations (with new equipment and/or sensors in some cases) while 12 are represented with new stations.

Table II - National coverage by AWS (Automatic weather station) and MWS (Manual weather station); $\mathrm{RG}$ - raingauge; BS, Cw, Am, Aw' (Köppen classification).

Quadro II - Cobertura nacional por AWS e MWS (Estações meteorológicas automática e manual, respectivamente); $R G$ - udómetros; $B S, C w, A m$, Aw' (Classificação de Köppen).

\begin{tabular}{|c|c|c|c|}
\hline Mun./sar & Location & $\begin{array}{l}\text { Agro-climatic } \\
\text { zone }\end{array}$ & Condition \\
\hline \multirow{3}{*}{$\mathrm{Al}$} & Quinta Portugal $^{\star}$ & $\mathrm{N}_{\text {up }}$ & Existing AWS; experimental farm \\
\hline & Acumau $\dagger$ & $\mathrm{N}_{\text {up }}$ & Existing AWS (representing also $\mathrm{DlxN}_{\mathrm{up}}$ ); historical relevance $(\mathrm{RG})$ \\
\hline & Aileu $\dagger$ & $\mathrm{N}_{\text {up }}$ & Existing AWS $\rightarrow$ MWS; historical relevance (MWS) \\
\hline \multirow{5}{*}{ An } & Urulefa $^{*}$ & $\mathrm{~S}_{\text {up }}$ & Existing AWS; experimental farm; mountainous zone ${ }^{\ddagger}$ \\
\hline & Ainaro $\dagger$ & $\mathrm{S}_{\text {up }}$ & Existing AWS; historical relevance (MWS) \\
\hline & Aituto $\dagger$ & $\mathrm{S}_{\text {up }}$ & Existing AWS; mountainous zone $e^{\ddagger}$ \\
\hline & Hato-Builico $\dagger$ & $\mathrm{S}_{\mathrm{up}}$ & Existing AWS; historical relevance (MWS); mountainous zone ${ }^{\ddagger}$ \\
\hline & Hato-Udo* & $\mathrm{S}_{\mathrm{sl}}$ & New AWS; historical relevance (RG) \\
\hline \multirow{7}{*}{$\mathrm{Bc}$} & Laga $\dagger$ & $\mathrm{N}_{\text {lw }}$ & New AWS; historical relevance (MWS); climatic relevance (BS) \\
\hline & Seiçal $^{\star}$ & $\mathrm{N}_{\mathrm{lw}}$ & Existing AWS \\
\hline & Fatumaca* & $\mathrm{N}_{\mathrm{sl}}$ & Existing AWS \\
\hline & Darasula $^{*}$ & $\mathrm{~N}_{\text {up }}$ & Existing AWS; experimental farm \\
\hline & Fatulia $\dagger$ & $\mathrm{N}_{\text {up }}$ & Existing AWS; mountainous zone (Baucau/Viqueque) \\
\hline & Baguia* $^{*}$ & $\mathrm{~S}_{\mathrm{sl}}$ & Existing AWS; historical relevance (MWS) \\
\hline & Triloro $\dagger$ & $\mathrm{N}_{\text {up }}$ & DNMG (Managing entity), historical relevance (MWS) \\
\hline \multirow{3}{*}{$\mathrm{Bb}$} & Maliana $^{*}$ & $\mathrm{~N}_{\mathrm{sl}}$ & Existing AWS; historical relevance (MWS) \\
\hline & Balibó $^{*}$ & $\mathrm{~N}_{\text {up }}$ & Existing AWS; historical relevance (RG) \\
\hline & Bobonaro* $^{*}$ & $\mathrm{~S}_{\mathrm{up}}$ & New AWS; historical relevance (MWS) \\
\hline \multirow{3}{*}{$\mathrm{Cv}$} & Suai $^{*}$ & $\mathrm{~S}_{\mathrm{lw}}$ & Existing AWS; historical relevance (RG) \\
\hline & Fohoren ${ }^{*}$ & $\mathrm{~S}_{\text {up }}$ & Existing AWS; historical relevance (MWS) \\
\hline & Zumalai* $^{*}$ & $\mathrm{~S}_{\mathrm{sl}}$ & New AWS; historical relevance (MWS) \\
\hline \multirow{4}{*}{ Dl } & Hera $^{*}$ & $\mathrm{~N}_{\mathrm{lw}}$ & Existing MWS $\rightarrow$ AWS; Agricultural college \\
\hline & Ataúro $\dagger$ & $\mathrm{N}_{\mathrm{lw}}$ & Existing AWS; historical relevance (MWS) \\
\hline & Dare $^{*}$ & $\mathrm{~N}_{\mathrm{sl}}$ & Existing AWS; historical relevance (MWS) \\
\hline & Comoro $\dagger$ & $\mathrm{N}_{\text {lw }}$ & DNMG (Managing entity); historical relevance (MWS) \\
\hline \multirow{4}{*}{ Em } & Gleno $^{*}$ & $\mathrm{~N}_{\text {up }}$ & Existing MW $\rightarrow$ AWS; historical relevance (MWS); experimental farm \\
\hline & Hato-Lia* & $\mathrm{N}_{\mathrm{sl}}$ & New AWS (representing LqxN $_{\mathrm{sl}}$ ); historical relevance (MWS) \\
\hline & Ermera $\dagger$ & $\mathrm{N}_{\text {up }}$ & Existing AWS; historical relevance (MWS); mountainous zone ${ }^{\ddagger}$ \\
\hline & Atsabe $\dagger$ & $\mathrm{N}_{\mathrm{up}}$ & $\begin{array}{l}\text { New MWS; historical relevance }(\mathrm{RG}) \text {; climatic relevance }(\mathrm{Cw}) \text {; } \\
\text { mountainous zone }\end{array}$ \\
\hline \multirow{3}{*}{ Lt } & Los Palos $\dagger$ & $\mathrm{S}_{\mathrm{sl}}$ & New AWS; historical relevance (MWS) \\
\hline & Luro $^{*}$ & $\mathrm{~N}_{\mathrm{sl}}$ & Existing AWS; historical relevance (RG); \\
\hline & Fuiloro $^{*}$ & $\mathrm{~S}_{\mathrm{sl}}$ & Existing AWS; historical relevance (RG); \\
\hline
\end{tabular}




\begin{tabular}{|c|c|c|c|}
\hline \multirow{3}{*}{ Lq } & Loes $^{*}$ & $\mathrm{~N}_{\mathrm{lw}}$ & Existing AWS; experimental farm \\
\hline & Liquiçáł & $\mathrm{N}_{\mathrm{lw}}$ & Existing MWS; historical relevance (MWS) \\
\hline & Fazenda Algarve* $^{*}$ & $\mathrm{~N}_{\text {up }}$ & Existing AWS; historical relevance (MWS) \\
\hline \multirow{6}{*}{ Mt } & Manatuto* $^{*}$ & $\mathrm{~N}_{\mathrm{lw}}$ & Existing AWS; historical relevance (MWS) \\
\hline & Laclubar* & $\mathrm{N}_{\text {up }}$ & Existing AWS; historical relevance (MWS); mountainous zone ${ }^{\ddagger}$ \\
\hline & Cribas* & $\mathrm{N}_{\mathrm{sl}}$ & Existing AWS \\
\hline & Soibada* & $\mathrm{S}_{\text {up }}$ & New AWS; historical relevance (MWS); climatic relevance (Am) \\
\hline & Barique $^{\star}$ & $\mathrm{S}_{\mathrm{sl}}$ & New AWS; historical relevance (MWS) \\
\hline & Natarbora* $^{*}$ & $\mathrm{~S}_{\mathrm{lw}}$ & Existing MWS $\rightarrow$ AWS; Agricultural school \\
\hline \multirow{3}{*}{ Mf } & Betano* $^{*}$ & $\mathrm{~S}_{\mathrm{lw}}$ & Existing AWS; experimental farm; historical relevance (RG) \\
\hline & Same $^{*}$ & $\mathrm{~S}_{\text {up }}$ & Existing AWS; historical relevance (MWS) \\
\hline & Dotik $^{*}$ & $\mathrm{~S}_{\mathrm{sl}}$ & Existing AWS \\
\hline \multirow{2}{*}{ Oc } & Pante Macassar ${ }^{\star}$ & $\mathrm{N}_{\mathrm{lw}}$ & Existing AWS; historical relevance (MWS) \\
\hline & Oi-Silo* $^{*}$ & $\mathrm{~N}_{\mathrm{sl}}$ & New AWS; historical relevance (RG) \\
\hline \multirow{4}{*}{$\mathrm{Vq}$} & Viqueque $\dagger$ & $\mathrm{S}_{\mathrm{lw}}$ & New AWS; historical relevance (MWS) \\
\hline & $\mathrm{Ossu}^{*}$ & $\mathrm{~S}_{\text {up }}$ & Existing AWS; historical relevance (MWS) \\
\hline & Illiomar* & $\mathrm{S}_{\mathrm{sl}}$ & New AWS; historical relevance (MWS); climate relevance (Aw') \\
\hline & Bahalara-uin* & $S_{l w}$ & Existing AWS \\
\hline
\end{tabular}

${ }^{*}$ Locations representing 35 combinations ( $m u n \times a c z$ ) and equipped in the $1^{\text {st }}$ stage/step; ${ }^{\dagger}$ Locations representing combinations reinforced by WS in the $2^{\text {nd }}$ stage/step; ${ }^{*}$ altitudes above $1000 \mathrm{~m}$.

When compared with the existing situation described above the following changes were recommended (fig. 4):

a) installation of 12 new WS in locations with relevant historical records: 11 AWS in Bobonaro (Bb), Soibada (Mn), Illiomar (Vq), Hato-Lia (Em), Barique (Mt), Zumalai (Cv), Viqueque (Vq), Lospalos (Lt), Laga (Bc), Oi-Silo (Oc) and Hato-Udo (An) and 1 MWS in Atsabe (Em). MWS have been active for decades in the first nine locations while rain gauges operated for more than a decade in the last three locations. The WS located in Viqueque belonged (such as Dili and Baucau) to regional and global networks (WMO) for decades;

b) suppression of 11 weather stations currently installed in Seloi Marlere (Al), Caraulum (Mf), Vemasse (Bc), Ritabau (Bb), Sahen (Mf), Irabere (Vq) Maubisse (An) Fuiloro (Lt) Balibó (Bb) Fohorem (Cv) and Betano (Mf);

c) replacement of a MWS by a AWS in Gleno (Em), Natarbora (Mn) and Hera (Dl) and replacement of a AWS by a MWS in Aileu (WS with historical relevance). In this latter case, the MMS will shortly be replaced by an AWS soon as there are financial resources to do so.

With these changes (a) 8 mun $x$ acz significant areas without any station currently

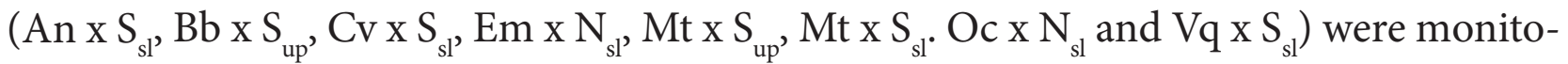
red, (b) most of the WS with relevant historical records and operational in 1975 (29 in out of 35) will become part of the national network, (c) more two locations with A $w^{\prime}$ climate (Lospalos, Illiomar) will be represented again, (d) both the representativeness of Am Climate type (Soibada, Hato-Lia) and B Climate type (Laga) in the territory will be strengthened. 6 locations with historical significance that were not included (for a while) 
in the national network (Fatu Bessi, Raimera, Alas, Lautém, Tutuala and Maubisse) will be well represented by WS located in Ermera, Same, Dotik, Luro, Fuiloro and Urulefa (geographical proximity, climate similarity).

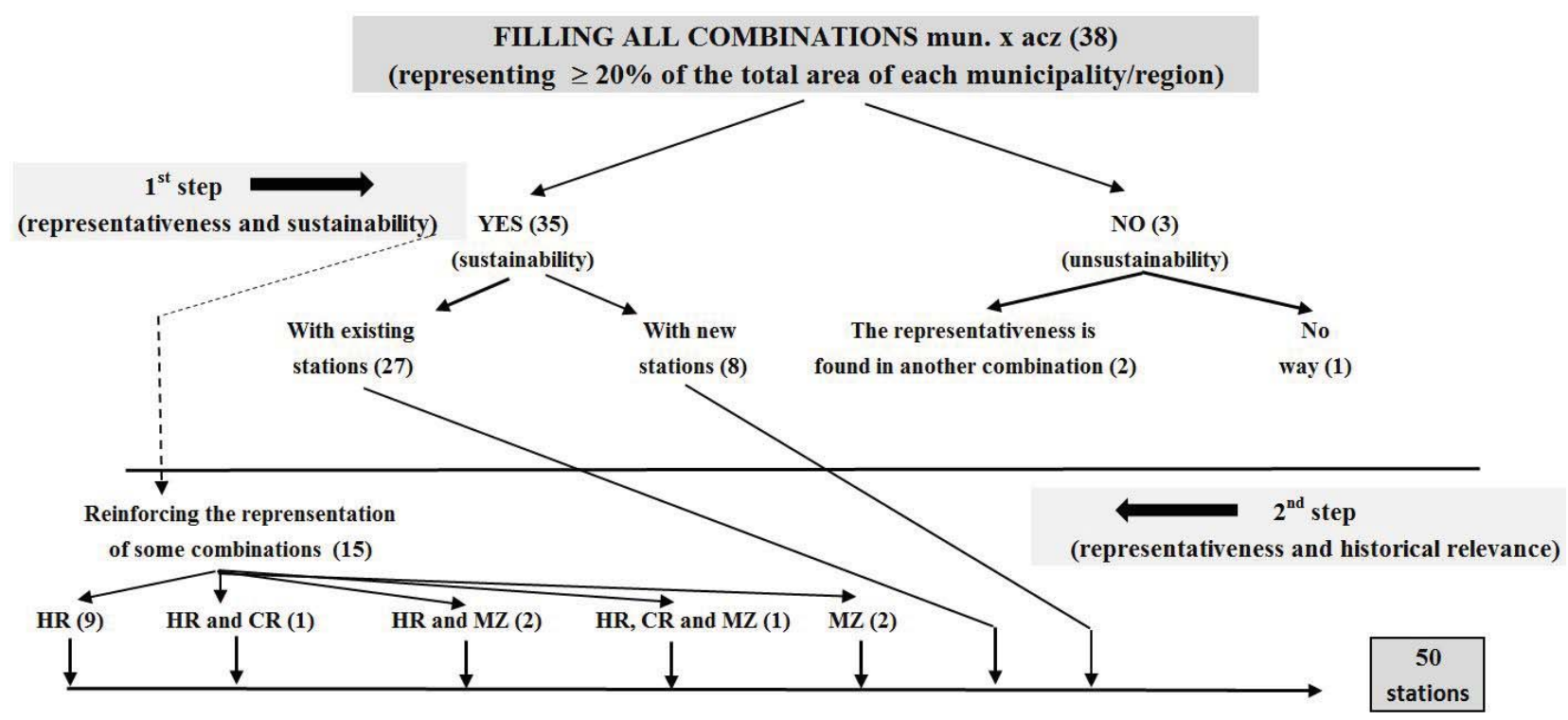

Fig. 4 - Filling the combinations (mun $x a c z$ ) that represent more than $20 \%$ of total area of each municipality by weather station and the criteria (representativeness, sustainability, historical relevance) associated to each of the two steps considered ( $1^{\text {st }}$ and $\left.2^{\text {nd }}\right)$. HR - Historical Relevance; CR - Climate Relevance; MZ - Mountainous Zone.

Fig. 4 - Distribuição de estações meteorológicas pelas combinações (mun x acz) que representam mais de $20 \%$ da área total de cada município e os critérios (representatividade, sustentabilidade, relevância histórica) associados a cada uma das duas etapas consideradas $\left(1^{a}\right.$ e $\left.2^{a}\right)$. HR - Relevância Histórica; CR - Relevância Climatológica; MZ - Zona Montanhosa.

\section{Network of agrometeorological stations}

The equipment in 15 out of 50 WS belonging to the national network should be strengthened with sensors of soil temperature and soil moisture. In the short term, sensors that measure parameters such as the evapotranspiration, the photosynthetic active radiation (PAR), the leaf wetness or parameters related to phenology and the appearance and spread of diseases will be also added in order to convert each of these stations into "auxiliary agricultural meteorological stations", according to the terminology of WMO (2010). Depending on criteria relating to changing conditions and objectives (agro-ecological zoning, financial resources, management conditions...), the composition of the network (number of stations, locations) may change over time.

The network of agrometeorological stations composed by these 15 stations (table III) (a) maintained a national coverage (for economic, administrative and social cohesion reasons), (b) express the existing climatic diversity in the country (climatic types Am, $\mathrm{A} w, \mathrm{~A} w, \mathrm{BS}, \mathrm{C} w),(\mathrm{c})$ represent the different (national) agro-climatic zones $\left(\mathrm{N}_{\mathrm{sw}}, \mathrm{N}_{\mathrm{sl}}, \mathrm{N}_{\mathrm{up}}\right.$, $\mathrm{S}_{\text {up }}, \mathrm{S}_{\mathrm{sl}}, \mathrm{S}_{\mathrm{lw}}$ ) and also highlands above $1000 \mathrm{~m}$, (d) included all the WS which are installed 
in experimental farms (agricultural or forestry), (e) serve to support the major agricultural extensions and strategic crops for the country (corn, rice, coffee and cassava), (f) represent the main watersheds (Loes, Laclo, Clere and Belles), (g) is present in the most important areas of forestry production (teak and sandalwood), (h) allows its sustainable management as well as the adequate and specialized maintenance of each of its stations (most of them will be located in experimental farms, agricultural schools and regional services of ALGIS/MAP), and also (i) ensures an easy and fast communication (real time) of the recorded data. 13 out of these 15 stations may operate with the current equipment (Enerco 420 or Hobo Standard, with communication by GSM or Satellite in the most remote locations). In Hera, a new complete AWS should be purchased. The new AWS located in Laklubar ( $\mathrm{Mn}$ ) should work with the equipment currently located in Fatumaca $(\mathrm{Bc})$. This latter change avoids additional financial expenses.

Table III - Agrometeorological stations included in the main network (main features).

Quadro III - Estações agrometeorológicas incluídas na rede principal (principais aspetos).

\begin{tabular}{|c|c|}
\hline Location (mun./sar $\mathrm{x}$ acz) & Main features \\
\hline Quinta Portugal $\left(\mathrm{Al} \mathrm{x} \mathrm{N}_{\text {up }}\right)$ & Experimental farm, cassava and coffee areas \\
\hline Urulefa $\left(\right.$ An x S up $_{\text {) }}$ & Experimental farm in a highland area, $\mathrm{Cw}$ climate type \\
\hline Ainaro $\left(A n \times S_{s l}\right)$ & $\begin{array}{l}\text { Coffee area in uplands with relevant historical records, Am climate type, } \\
\text { Belles basin }\end{array}$ \\
\hline Maliana $\left(\mathrm{Bb} \times \mathrm{N}_{\mathrm{sl}}\right)$ & Extensive rice paddies in west, Am climate type \\
\hline Darasula $\left(\mathrm{Bc} \times \mathrm{N}_{\mathrm{up}}\right)$ & Experimental station in the plateau of Baucau \\
\hline Fohorem (Cv x Sup) & Agriculture, livestock and forestry (sandal zone) activities. \\
\hline $\operatorname{Hera}\left(\mathrm{Dl} \mathrm{x} \mathrm{N_{1w } )}\right.$ & Research centre located in lowlands of the north coast (Dili area) \\
\hline Gleno $\left(\mathrm{Em} \times \mathrm{N}_{\text {up }}\right)$ & Experimental farm in an area of coffee plantations \\
\hline Lospalos $\left(\operatorname{Lt~x~S}_{\mathrm{sl}}\right)$ & $\begin{array}{l}\text { Extensive east cornfields with relevant historical records in plateau areas } \\
\text { of Aw' climate }\end{array}$ \\
\hline Loes $\left(\mathrm{Lq} \times \mathrm{N}_{\mathrm{lw}}\right)$ & $\begin{array}{l}\text { Western experimental farm in extensive rice paddies and cornfields near the } \\
\text { mouth of the Loisy }\end{array}$ \\
\hline Manatuto ( $\mathrm{Mn} \times \mathrm{N}_{\mathrm{lw}}$ ) & $\begin{array}{l}\text { Extensive rice paddies in the northern coast with BS climate type, near the } \\
\text { mouth of the Lacló }\end{array}$ \\
\hline Laklubar $\left(\mathrm{Mn} \times \mathrm{N}_{\text {up }}\right)$ & In the middle of the hill crest, Aw climate type, coffee area \\
\hline $\operatorname{Betano}\left(\mathrm{Mf} \mathrm{x} \mathrm{S}_{\mathrm{lw}_{\mathrm{w}}}\right)$ & $\begin{array}{l}\text { Experimental farm in the lowlands of the south coast, near the mouth of the } \\
\text { Caraulum, Aw' climate type }\end{array}$ \\
\hline Pante Macassar $\left(\mathrm{Oc} \times \mathrm{N}_{\mathrm{lw}}\right)$ & Rice paddies in lowlands in the Oecusse enclave (north coastal) \\
\hline Viqueque $\left(\mathrm{Vq}_{\mathrm{x}} \mathrm{S}_{\mathrm{sl}}\right)$ & Relevant historical records in areas of A $w^{\prime}$ climate at south coast, teak zone \\
\hline
\end{tabular}

Setting up a national network of agrometeorological stations under the responsibility of the public authorities presupposes the existence of a national meteorological network with diverse applications and with competent coverage of all the existing climatic diversity. The model of public management is followed by most countries in Asia and Oceania, but the functional link between the networks of agrometeorological and meteorological 
stations, when it exists, differs from country to country (Boer, Hilario, McGree, Pajuelas, \& Sehg, 2004; Kamali et al., 2006). This diversity of solutions requires an operability of networks and meteorological services necessarily adapted to each specific situation. In Timor-Leste, a permanent link between the agrometeorological network and the national weather stations network (as proposed in this work) was established (the first is part of the second). As both networks are managed by the same public authority (ALGIS/MAP, except for the WS installed in Comoro and Triloro, managed by DNMG) the long-term sustainability of the link between them is reinforced. A reinforced articulation between the network of installed stations and the rainwater monitoring network operating under the responsibility of the National Directorate for Water Quality and Control (another Timorese public authority) is a continuing need in Timor-Leste, mainly due to its rugged relief.

The successful establishment of a network of weather stations (or agrometeorological stations) is largely based on the flexibility of the criteria adopted, which should be even greater in situations where agro-climatic factors are only a part of the factors considered, as is often the case in developing countries. The composition of both networks and the relative importance of agrometeorological network in the national network should be flexible, with any change in both networks resulting from the needs arising from technical, social and economic issues. Without ever losing sight of the most stringent scientific criteria, the solutions chosen should reflect the current capacity for a strict and an accurate management of all weather stations included in any network.

Ensuring a proper management of the networks make them sustainable in the long term, avoiding data loss due to a shortage of financial and human resources. In fact, changing a station from one location to another or installing a new station in a place chosen for this purpose may not be feasible, whenever on-site maintenance is not assured. The non-choice (or postponement) of 6 locations with relevant records in historical terms (Maubisse, Alas, Fatu-Bessi, Lautém, Tutuala and Raimera) is an example of the impossibility of ensuring in the short-term, with the existing resources, the sustainability of proper management of the network. This sustainability requires qualified human resources in each place to ensure the basic tasks of maintenance, the permanent training of technical personnel to ensure the continuity of this long-term project and permanent contact with the local population by making his members (farmers and their families, political and social representatives) partners of the network management. Also an easy access for the technical supervisors at the locations where they are installed and a real-time communication warranty with an operating centre (usually placed in the capital) must be assured. In short, without a "concept of weather stations management" the success of the installation of a weather station or a network of weather stations cannot be guaranteed (Andrade, 2015). Technical experimental stations and agricultural schools should then have a central role in the management and maintenance of the stations belonging to the agrometeorological network, avoiding most of the usual shortcomings and limitations that weaken the availability and application of agrometeorological data (Stefanski, 2006). Achieving the goals will enable a wider compliance with WMO rules for the establishment of agrometeorological stations and their networks. 
Finally, the validity of the criteria is another issue. For example, the agro-climatic classification used (ARPAPET, 1996) presents some weakness (e.g., altitude limits used to separate the different zones, distinction between temperate and tropical zones, absence of the edaphic factor). Then a new reorganization of the network should therefore be based on a more improved agro-ecological zoning.

\section{CONCLUDING REMARKS}

The establishment of jointly managed weather and agrometeorological stations (constituting networks) is strongly advisable to fulfil their role in the economic (and agricultural) development policies of the Timorese territory.

Taking into account the basic needs and available resources (financial and human) it was possible to propose the establishment of a meteorological network with 50 stations, 15 of them with the specific aim of supporting the agricultural and forestry activities in Timor-Leste constituing a network of agrometeorological stations included in the former, both covering the entire territory of Timor-Leste.

Flexibility (replacement and reclassification of stations) should be a basic feature of any management concept, allowing quick and effective responses to possible changes in the factors taken into account (political, socioeconomic or even agro-climatic zoning). The composition of each network should therefore vary in time whenever the status of each station changes due to the changing conditions and objectives.

The adopted methodology (factors and criteria taken into account) may be replicated in similar situations, mainly in countries or regions without regular long-term data, with limited financial resources and increased responsibilities of the public sector in the establishment of national networks and meteorological and/or agrometeorological stations.

\section{ACKNOWLEDGEMENTS}

This paper resulted from a consultancy executed by the first author in Timor-Leste (November 2014 to January 2015). We thank the Global Climate Change Alliance Programme Timor-Leste.

\section{REFERENCES}

Andrade, J. (2015). Um conceito de gestão para as estações meteorológicas de Timor-Leste [A management concept for the weather stations in Timor-Leste]. Dili: GCCA-TL.

Advanced Research Projects Agency Network. (ARPAPET). (1996). Agro-climatic zones of East Timor. Dili, Timor, Indonesia: Indonesia-Australia
Development Corporation. Agricultural and Regional Planning Assistance Program East Timor, Kantor Wilayah Department Pertaining Propensity Timor.

Arsenault, R., \& Brissette, F. (2014). Determining the optimal spatial distribution of weather station networks for Hydrological Modelling purposes 
using RCM databases; an experimental approach. Journal of Hydrometeorology, 15(1), 517-526. doi: 10.1175/JHM-D-13-088.1

Boer, R., Hilario, F. D., McGree, S., Pajuelas, B. G., \& Sehg, T. L. (2006). Perspectives from Regional Association V (South-West Pacific). In R. P. Motha, M. V. K. Sivakumar \& M. Bernardi (Eds.), Strengthening Operational Agrometeorological Services at the national Level (pp. 69-75). Washington, D.C.: WMO and FAO.

Czaczyk, Z. (2012). Evaluation of the existing meteorological stations for the agrometeorological protection of agriculture in Wielkopolska. Journal of Plant Protection Research, 52(2), 290-297. doi: 10.2478/v10045-012-0047-y

Kamali, A., Van Viet, N., \& Rahimi, M. (2006). Perspectives from Regional association II (Asia). In R. P. Motha, M. V. K. Sivakumar \& M. Bernardi (Eds.), Strengthening Operational Agrometeorological Services at the national Level (pp. 24-33). Washington, D.C.: WMO and FAO.

Katušin, Z. (1994). Meteorological stations network in Croatia and Wars. Hrvatski meteorolološki časopis, 29, 47-56.

Peel, M. C., Finlayson, B. L., \& McMahon, T. A. (2007). Update world map of the Köppen-Geiger climate classification. Hydrol. Earth Syst. Sci. 11, 1633-1644. doi: 10.5194/hess-11-1633-2007

Seeds of Life. (2013). Topography of Timor-Leste.png. Retrieved from https://commons.wikimedia.org/ wiki/File:Topography of Timor\%E2\%80\%91 Leste.png

Sousa, E. (1972). Esboço duma caracterização agro-climática da província de Timor [Draft of an agro-climatic characterization of Timor province]. Lisboa: Junta de Investigações do Ultramar.

Stefanski, R. (2006). Strehgthening Operational Agrometeorological Services: a Critical Review. In R. P. Motha, M. V. K. Sivakumar \& M. Bernardi
(Eds.), Strengthening Operational Agrometeorological Services at the national Level (pp. 128-136). Washington, D.C.: WMO and FAO.

United Nations Educational, Scientific and Cultural Organization. (UNESCO). (2015). Knoema. Atlas mundial de dados [World Data Atlas-Knoema]. Timor Leste: UNESCO. Retrieved from http://pt. knoema.com/atlas/Timor-Leste/topics

Universidade Técnica de Lisboa. (UTL)., \& Faculdade de Arquitectura de Lisboa. (FA). (2002). Atlas de Timor Leste [Timor-Leste Atlas]. Lisboa: LIDEL-Edições Técnicas.

van Wart, J., Lenny, G. J., van Bussel, J. G. L., Wolf, J., Licker, R., Grassini, P... Cassmana, K. G. (2013). Use of agro-climatic zones to upscale simulated crop yield potential. Field Crops Research, 143, 44-55. doi: 10.1016/j.fcr.2012.11.023

Timor Agora. (2015). Sucos timorenses devem estar no centro da descentralização administrativa do país-CNE [Timorese 'juices' should be at the heart of the country's administrative decentralization CNE]. Retrieved from http://timoragora.blogspot.pt/2015/04/sucos-timorenses-devem-estar-no-centro.html

World Meteorological Organization. (WMO). (2014). Guide to Meteorological Instruments and Methods of Observation. No 8. Genéve: World Meteorological Organization.

World Meteorological Organization. (WMO). (2011). Guide to Climatological Practices. No 100. Genéve: World Meteorological Organization.

World Meteorological Organization. (WMO). (2010). Guide to Agricultural Meteorological Practices. No 134. Genéve: World Meteorological Organization.

World Meteorological Organization. (WMO). (2007). Climate information for adaptation and development needs. No 1025. Genéve: World Meteorological Organization. 